\title{
Comparative Scanning Electron Microscopy of Platelets and Fibrin Networks of Human and Differents Animals
}

\author{
Microscopía Electrónica de Barrido Comparativa de Plaquetas \\ y Redes de Fibrina de Humano y de Diferentes Animales
}

"Pretorius, E.; "Vieira, W. A.; "Oberholzer, H. M. \& **Auer, R. E. J.

PRETORIUS, E.; VIEIRA, W. A.; OBERHOLZER, H. M. \& AUER, R. E. J. Comparative scanning electron microscopy of platelets and fibrin networks of human and differents animals.Int. J. Morphol., 27(1):69-76, 2009.

SUMMARY: The purpose of the present study was to compare the platelet and fibrin network ultrastructure of humans to eight different animal species in order to determine the differences between human and animal platelet and fibrin morphology, and to determine whether the animals studied differ in their platelet and fibrin morphology, and whether these differences can be observed by scanning electron microscopy. Platelets and fibrin networks play an important role both in the coagulation process as well as physiologically in allergic processes and immunological mechanisms. The thickness of human fibrin networks were compared to mouse (Mus musculus), equine (Equus caballus), vervet monkey (Chlorocebus aethiops previously Cercopithecus aethiops), oryx (Oryx gazella), ovine (Ovis aries), penguin (Spheniscus demersus), rabbit (Oryctolagus cuniculus) and sea turtle (Caretta caretta). Fibers were measured and divided into thin (minor) fibers, intermediate fibers and thick (major) fibers. The results obtained indicated that for each of the three fibrin classes, the size ranges of the monkey, oryx and equine were not significantly different to one another, and the human, penguin, oryx and ovine not significantly different to one other. From these results it can be concluded that mammals and aves possess a distinct tri-modal fibrin fiber distribution, different from that of the studied reptilian species where the sea turtle possesses a distinct bimodal fibrin fiber distribution and it can be suggested that the utilization of mammalian and avian models, in terms of fibrin fiber distribution patterns, might be a suitable alternative for ultrastructural studies.

KEY WORDS: Scanning electron microscopy; Platelets; Fibrin networks; Human; Animals.

\section{INTRODUCTION}

Platelets and fibrin play an important role in the coagulation process where they are involved in the maintenance of haemostasis (Herd \& Page, 1994). However, they also play an important physiological role in allergic processes and other immunological mechanisms. In conditions like allergic asthma, platelets participate by acting as inflammatory cells, by releasing mediators, spasmogens and/or by interacting with other inflammatory cell types. These mediators include enzymes active in the coagulation cascade. Platelets are activated by a number of stimuli resulting in the expression and/or activation of surface receptors, secretion of vaso-active substances, adhesion, aggregation, and finally thrombus formation (Lazarus et al., 2003). The activation may be due to damage of the vessel wall or activation of the endothelium by chemicals, cytokines, and also inflammatory processes (Camera et al.,
1999; Butenas \& Mann, 2002) typically involved in conditions like allergic asthma. Fibrin dysfunction is associated with the development of vascular complications, while proneness to the formation of tight and rigid fibrin networks is independently associated with thrombotic disease In animals, thrombotic disease is scarce animals like dogs, sheep and horses, but is known to occur in cats.

However, few studies have examined the ultrastructure of platelets and fibrin networks in animals. The animals studied included rhinoceros, elephant and bovine species (Zucker-Franklin et al., 1985; Ebbeling et al., 1992; du Plessis et al., 1996; Cheryk et al., 1998; Liu et al., 1998; du Plessis \& Stevens, 2002). Ebbeling et al. in 1992 studied the TEM ultrastructure of human platelets. After thrombin addition, platelets formed pseudopodia and centralized their

\footnotetext{
* Department of Anatomy, School of Medicine, Faculty of Health Sciences, University of Pretoria, South Africa.

** University of Pretoria Biomedical Research Centre, University of Pretoria, South Africa.
} 
granules. Cheryk et al. studied the ultrastructure of platelets from the Asian elephant (Elephas maximus) before and after activation with the agonist platelet activating factor (PAF) using the TEM. The authors found that the unactivated platelets have a distinct ultrastructural appearance and that the cytoplasm contained large, randomly distributed granules with no internal cristae that typify the open canalicular system in other mammalian platelets. After PAF stimulation, large aggregates of platelets form, however, many platelets remained discrete entities. After aggregation some platelets were swollen and the internal granules were absent, while others retained their granules. Some platelets also developed gap-like features on the outer membranes.

Liu $e t$ al. studied the effect of procainamide on the ultrastructure of human blood platelets. It was found that procainamide inhibited the changes of ultrastructure of blood platelets and releasing responses and found changes of pseudopods, alpha-granules, dense granules, glycogens, open canalicular system, and dense tubular system.

The internal platelet ultrastructure of the African elephant, by using the light microscope, SEM and TEM was also studied (du Plessis \& Stevens). SEM analysis showed that the platelets were pleomorphic, while blood smears showed platelets with numerous pseudopodia. Buffalo (Syncerus caffer), bovine (Bos taurus) and human platelet morphology was also studied using the TEM (du Plessis $e t$ $a l$.). Human platelets have pseudopodia and intracellular agranules as well as surface-connecting canaliculi; bovine platelets have a smooth surface, a-granules, as well as distinctive dense bodies in the cytoplasm and buffalo platelets closely resembled that of bovine platelets.

Animals like rabbits and mice have long been used successfully as animal models, and are often the species of choice for models of anti-thrombotic efficacy. Pretorius et al. (2007) have shown that the ultrastrucuture of rabbit and human platelet and fibrin morphology are very similar in ultrastructure and fibrin fiber thickness, however, mouse fibers differ in thickness to that of both human and rabbit fibrin. These findings could have implications for further clinical research.

The question that now arose is whether different classes and orders of animals have different platelet and fibrin morphology, and whether these differences might be seen using the SEM. This might give valuable insight into the physiology of the animals or perhaps even be used in later phylogenetic studies.

Therefore, in the current study we compare the fibrin networks thickness of humans to the mouse (Mus musculus), equine (Equus caballus), vervet monkey (Chlorocebus aethiops previously Cercopithecus aethiops), oryx (Oryx gazella), ovine (Ovis aries), penguin (Spheniscus demersus), rabbit (Oryctolagus cuniculus) and sea turtle (Caretta caretta).

\section{MATERIAL AND METHOD}

Samples. Samples consisted of eight different animal species - one avian, one reptilian and six mammalian species (mouse, equine, monkey, oryx, ovine, penguin, rabbit and sea turtle). One sample per species were analysed and sample were systematically viewed to determine the consistency of the ultrastructure.

Their fibrin networks were compared to fibrin networks of control humans. Ethical clearance form the Human Ethical Committee from the University of Pretoria (151/2006) was obtained. Blood samples were collected by venipuncture as part of the AUCC approved project no H26/06.

Preparation of the blood sample to obtain a fibrin clot. All blood was collected in citrate tubes and stored at $4{ }^{\circ} \mathrm{C}$ and processed shortly after collection. Freshly prepared platelet rich plasma (FPRP), was prepared by centrifuging blood at $1000 \mathrm{rpm}$ for 2 minutes. $20 \mu \mathrm{l}$ of the FPRP was mixed with $20 \mu \mathrm{l}$ thrombin on a $0.2 \mu \mathrm{m}$ millipore membrane to form the coagulate (fibrin clot). The filter was placed in a Petri dish on filter paper dampened with phosphate buffered saline (PBS) to create a humid environment and placed a $37^{\circ} \mathrm{C}$ for 10 minutes. This was followed by a washing process where the millipore membranes containing coagulate were placed in PBS and magnetically stirred for 2 hours. Blood proteins trapped within the fibrin network were removed in this way.

Preparation of the washed fibrin clot for scanning electron microscopy (SEM). Washed fibrin clots were fixed in $2.5 \%$ gluteraldehyde in Dulbecco's phosphate buffered saline (DPBS) buffer with a pH of 7.4, for 1 hour. Each fibrin clot was rinsed three times in phosphate buffer for 5 minutes before being fixed for 1 hour with $1 \%$ osmium tetra-oxide $\left(\mathrm{OsO}_{4}\right)$. The samples were rinsed 3 times with distilled water for 5 minutes each rinse and dehydrated serially in 30\%, $50 \%, 70 \%$ and $90 \%$ ethanol and three times with $100 \%$ ethanol. The SEM procedures were completed by critical point drying of the material, mounting and examining of the tissue using a JEOL 6000F FEGSEM.

Analysis of fibrin networks. Fibrin networks were then visualized with SEM and micrographs taken at 10000 times 
magnification. Within each photographed network, 100 fibers were selected at random and marked with the utilization of Microsoft Photo Premium version 10. The selected fibers were subsequently quantified in terms of their diameters, at the specified positions, with the aid of UTHSCSA Image tool version 3.00 .

\section{RESULTS}

Figure 1 shows the micrographs of the different animals and human fibrin networks. In the current study, the acquired fibrin diameters, from each sample, were first assessed with a Sharpiro-Wilk W test for normality, in NCSS. The construction of frequency histograms followed, in NCSS, for each of the samples to allow for the distribution of the fibrin diameters to be quantified in terms of any visually distinct size classes. The visually discerned size classes, for each sample, were then utilized for the

Table I. Analysis of the fibrin fibers diameters distributions with the aid of Sharpiro-Wilk W test for normality.

\begin{tabular}{lcl}
\hline Animal & P-value* $^{*}$ & Implication \\
\hline Equine & $2.448 \mathrm{E}-07$ & \\
Human & $1.94 \mathrm{E}-07$ & \\
Monkey & $2.81 \mathrm{E}-06$ & \\
Mouse & $1.01 \mathrm{E}-06$ & Data does assume \\
Oryx & $3.09 \mathrm{E}-04$ & a normal distribution \\
Ovine & $1.21 \mathrm{E}-05$ & \\
Penguin & $7.68 \mathrm{E}-11$ & \\
Rabbit & $2.51 \mathrm{E}-05$ & \\
Sea turtle & $1.10 \mathrm{E}-11$ & \\
\hline
\end{tabular}

*Significance was set at a level of 0.05 . classification of the measured diameters. The classed fibers were compared statistically, both within and between each subject, with the aid of one-way ANOVA's or Kruskal-Wallis one-way ANOVA's - depending upon whether the necessary assumptions for the parametric test were met or not - to ascribe significance, if any, to the constructed fibrin size classes. The number of fibers ascribed to each of the constructed size classes differed, and as a result a random set of fibers were chosen from each size class, for each subject, to allow for the comparison of equal sample sizes. This allowed for the assumption of equal variance to be ignored.

The Sharpiro-Wilk W test for normality utilized for each of the samples revealed, as expressed in Table I, that the fibrin fiber diameters were not normally distributed.

Histogram analysis revealed that there is a tri-modal count frequency distribution within each of the assessed fibrin diameters for each of the samples. An example of a histogram for the human fiber distribution, is shown in Figure 2 (each size class designated with a black line).

Table II shows the actual size distribution of the 3 types of fibers: thin (minor), intermediate and thick (major).

Table III shows the within group statistical analysis of the constructed fibrin size classes. Also, between group statistical analysis of the three constructed fibrin size classes were performed and a $\mathrm{p}$ value of $<0.000001$ was obtained.

Table II. The fibrin fiber diameter size ranges associated with each assessed subjects fibrin size classes.

\begin{tabular}{lccc} 
Animal & $\begin{array}{c}\text { Thin fiber } \\
\text { diameter range }(\mathbf{n m})\end{array}$ & $\begin{array}{c}\text { Intermediate fiber } \\
\text { diameter range }(\mathbf{n m})\end{array}$ & $\begin{array}{c}\text { Thick fiber } \\
\text { diameter range (nm) }\end{array}$ \\
\hline Equine & $11-48$ & $49-149$ & $150-250$ \\
Human & $23-84$ & $85-202$ & $203-441$ \\
Monkey & $16-59$ & $60-142$ & $143-309$ \\
Mouse & $4-21$ & $22-37$ & $38-60$ \\
Oryx & $25-70$ & $71-159$ & $160-338$ \\
Ovine & $14-133$ & $134-168$ & $169-286$ \\
Penguin & $19-124$ & $125-181$ & $182-391$ \\
Rabbit & $9-48$ & $49-86$ & $87-149$ \\
Sea turtle* & $19-129$ & & $130-400$ \\
\hline
\end{tabular}

* Proven statistically to possess a fibrin network composed of only thick and thin fibrin fibers. 

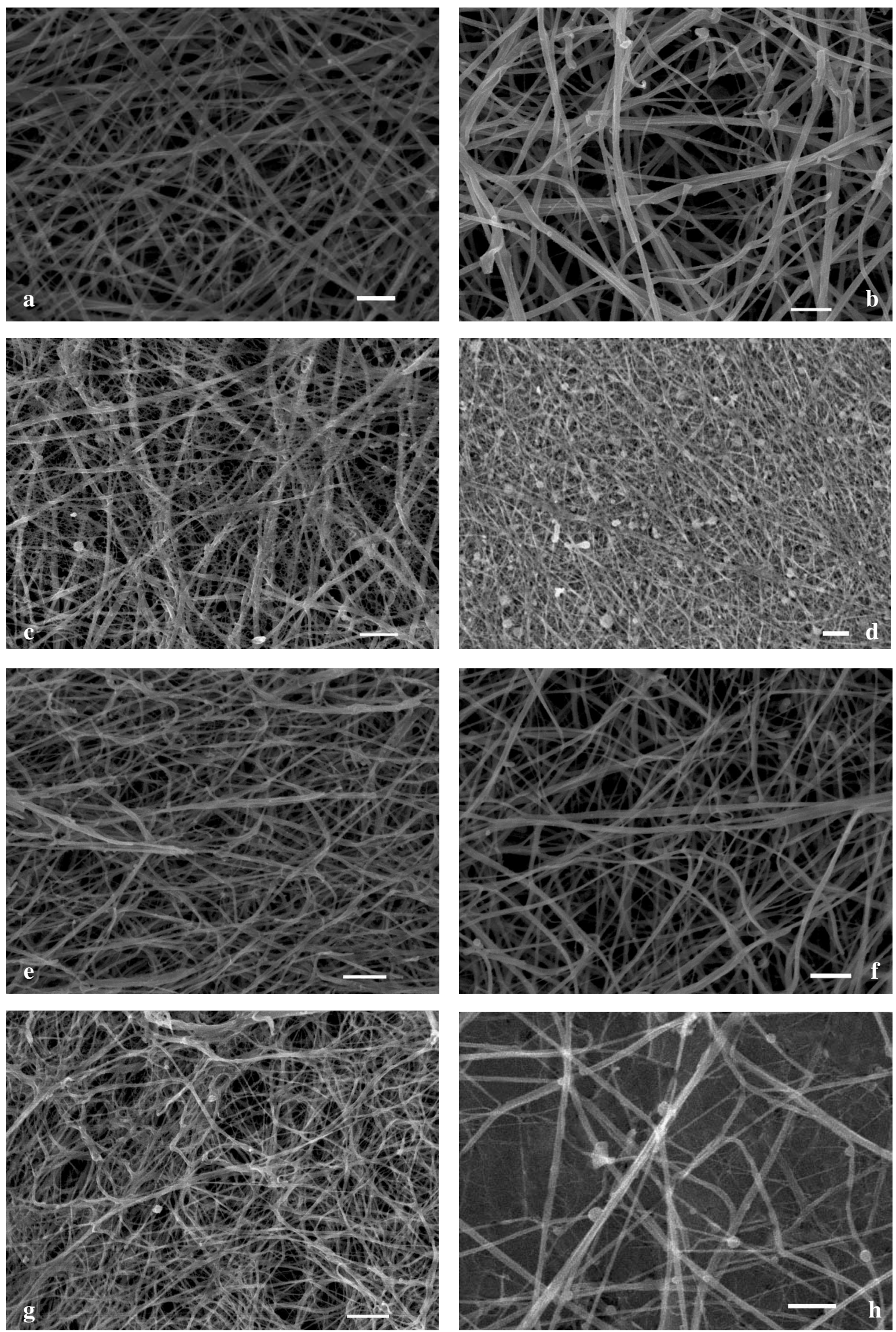

Fig. 1. Fibrin networks of humans (a), oryx (b), ovine (c), penguin (d), equine (e), monkey (f), sea turtle (g) and rabbit (h). Scale bar $=1 \mu \mathrm{m}$ 
Table III. The within group statistical analysis of the constructed fibrin size classes.

\begin{tabular}{|c|c|c|c|}
\hline Animal & Test utilized & P value* & $\begin{array}{l}\text { Within group fiber class differences } \\
\text { determined, if applicable, with the aid of } \\
\text { Tukey-Kramer Multiple-Comparison Test's }\end{array}$ \\
\hline Equine & One-way ANOVA & $<0.000001$ & \multirow{7}{*}{$\begin{array}{l}\text { Thick fibrin fibers significantly larger in } \\
\text { diameter than both the intermediate and thin } \\
\text { fibrin fibers. } \\
\text { Intermediate fibrin fibers significantly larger in } \\
\text { diameter than the thin fibrin fibers. }\end{array}$} \\
\hline Human & Kruskal-Wallis one-way ANOVA & & \\
\hline Monkey & Kruskal-Wallis one-way ANOVA & $<0.000001$ & \\
\hline Mouse & Kruskal-Wallis one-way ANOVA & 0.000036 & \\
\hline Oryx & One-way ANOVA & $<0.000001$ & \\
\hline Ovine & One-way ANOVA & $<0.000001$ & \\
\hline Penguin & Kruskal-Wallis one-way ANOVA & 0.000135 & \\
\hline Rabbit & One-way ANOVA & $<0.000001$ & \\
\hline $\begin{array}{l}\text { Sea turtle (assuming a tri-modal } \\
\text { fibrin distribution pattern) }\end{array}$ & Kru skal-Wallis one-way ANOVA & 0.000015 & $\begin{array}{l}\text { Thin and intermediate fibrin fibers both } \\
\text { significantly smaller than the thick fibrin fibers } \\
\text { but not significantly different to each other. }\end{array}$ \\
\hline $\begin{array}{l}\text { Sea turtle (assuming a } b \text { imodal } \\
\text { fibrin distribution pattern) }\end{array}$ & $l$ Kruskal-Wallis one-way ANOVA & 0.000157 & $\begin{array}{l}\text { Thin fibrin fibers significantly smaller than the } \\
\text { thick fibrin fibers. }\end{array}$ \\
\hline
\end{tabular}

* Significance was set at a level of 0.05 .

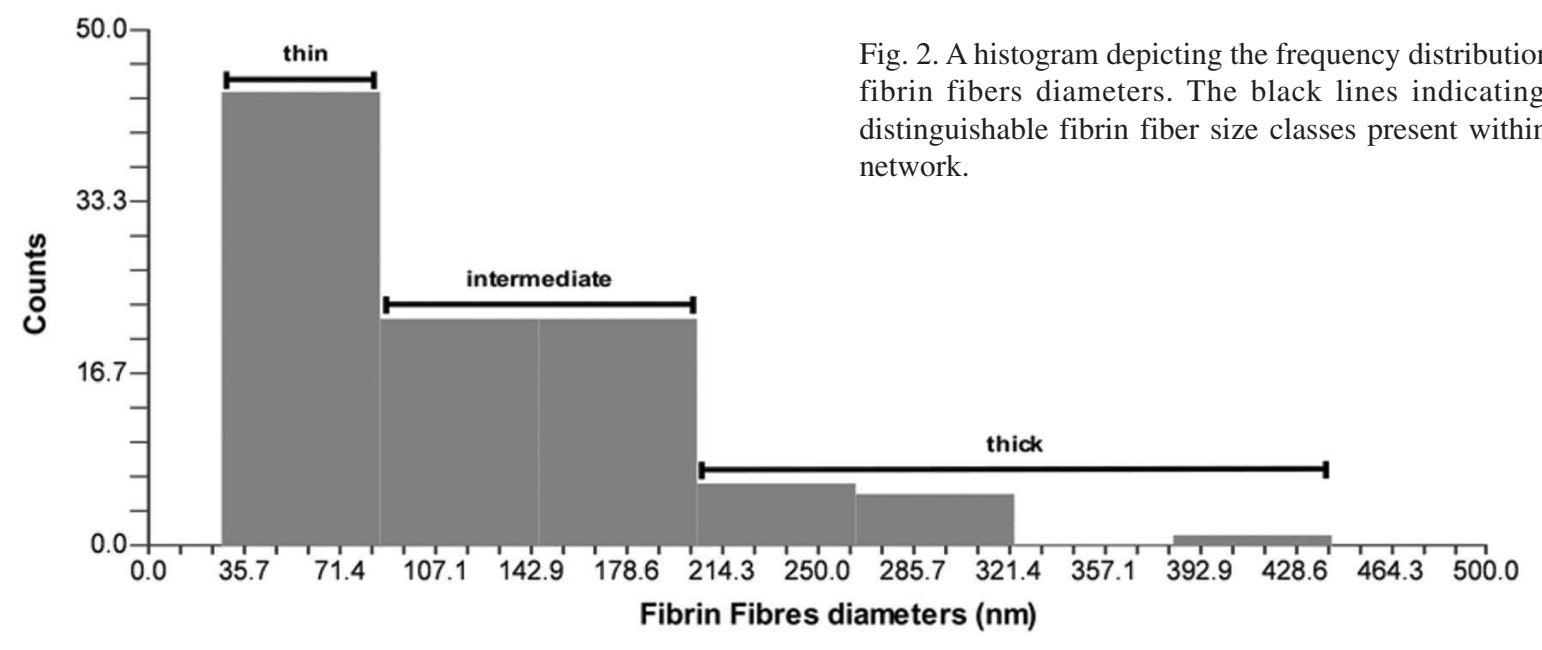

\section{DISCUSSION}

The literature pertaining to fibrin networks suggests that a typical fibrin network is composed of distinct thick (major) and thin (minor) fibrin fibers. One would expect that such a pattern, upon statistical quantification, would possess a typical bimodal distribution of fibrin diameters - hence lacking the classical "bell shape" distribution pattern. Therefore, in the current study, the acquired fibrin diameters, from each sample, were first assessed with a Sharpiro-Wilk W test for normality, in NCSS. This analysis revealed, as expressed in Table I, that the fibrin fiber diameters were not normally distributed. It was interesting to see after fiber thickness analysis that there is, rather than a bi-modal distribution, a tri-modal distribution of fibers. Therefore, instead of only typical minor (thin) fiber and 
major (thick) fibers noted in the literature, an intermediate fiber thickness also exists. The distribution was seen in all the samples and Fig. 2 shows the histogram for the human sample.

Table III reveals that, for each of the mammalian species, as well as the single avian species, the three fibrin size classes derived from the constructed histograms were significantly different from one another; hence each of these animals possessed a significant tri-modal blood clot fibrin fiber diameter distribution. Only in the cases of the equine, oryx and ovine were the necessary assumptions of normality met allowing for the utilization of the parametric one-way ANOVA. Within all the other mammalian and avian samples, the data failed to meet the assumption of normality, resulting in the use of the non-parametric Kruskal-Wallis one-way ANOVA test.

The statistical assessment of the tri-modally classified fibrin fibers for the sea turtle through a KruskalWallis one way ANOVA revealed that the thin and intermediate fibrin fibers were both significantly smaller than the thick fibrin fibers but not significantly different to each other. This statistically proves the absence of a trimodal fibrin distribution within this reptilian species. In order to assess if a bimodal distribution was present, the thin and intermediate size ranges denoted for this subject were combined, and the fibers re-classified and then assessed via a Kruskal-Wallis one way ANOVA - as the assumptions of normality were not met. As expressed in table three the sea turtle has a significant bimodal fibrin fiber diameter distribution.

The denoted fibrin size classes were compared between the various subjects via Kruskal-Wallis one-way ANOVA's, due to the lack of normality within the analyzed data. The various the samples differed significantly from each other, within each fibrin size class. A p-value of $<$ 0.000001 was obtained. The following was noted:

\section{Thin (Minor) fiber analysis.}

- Mouse: significantly different to all the other species.

- Rabbit: significantly different to that of the human, penguin, ovine and the sea turtle.

- Equine: significantly different to that of the mouse, penguin, ovine and the sea turtle.

- Monkey: significantly different to that of the mouse and the sea turtle.

- Oryx: significantly different to that of the mouse and the sea turtle. - Human: significantly different to that of the mouse, rabbit and the sea turtle.

- Penguin: significantly different to that of the mouse, rabbit, equine and the sea turtle.
- Ovine: significantly different to that of the mouse, rabbit, equine and the sea turtle.

- Sea turtle: significantly different to all the other species.

\section{Intermediate fiber analysis.}

- Mouse: significantly different to all the other species.

- Rabbit: significantly different to that of the mouse, monkey, oryx, human, penguin, and the ovine.

- Equine: significantly different to that of the mouse, human, penguin and the ovine.

- Monkey: significantly different to that of the mouse, rabbit, penguin and the ovine.

- Oryx: significantly different to that of the mouse and the rabbit.

- Human: significantly different to that of the mouse, rabbit and the equine.

- Penguin: significantly different to that of the mouse, rabbit, equine and the monkey.

- Ovine: significantly different to that of the mouse, rabbit, equine and the monkey.

\section{Thick (Major) fiber analysis.}

- Mouse: significantly different to all the other species analyzed.

- Rabbit: significantly different to that of the mouse, equine, oryx, ovine human and penguin analyzed.

- Sea turtle: significantly different to that of the mouse, OV, human and the penguin analyzed.

- Monkey: significantly different to that of the mouse, human and the penguin analyzed

- Equine: significantly different to that of the mouse and rabbit analyzed.

- Oryx: significantly different to that of the mouse and the rabbit analyzed.

- Ovine: significantly different to that of the mouse, rabbit and the sea turtle analyzed.

- Human: significantly different to that of the mouse, rabbit and sea turtle and the monkey analyzed.

- Penguin: significantly different to that of the mouse, rabbit and sea turtle and the monkey analyzed.

Therefore it can be concluded that for all fibrin size classes, the size ranges of the monkey, oryx and equine were not significantly different to one another, as well as for those for the human, penguin, oryx and ovine not being significantly different to one other. It should be noted that further studies would need to be conducted in order to determine if the tri-modal and bimodal fibrin distribution patterns are class or species specific for the avian and reptilian classes, respectively.

From the study conducted it could be concluded that mammals and Aves possess a distinct tri-modal fibrin fiber distribution, different from that of the studied reptilian species. The sea turtle could be seen to possess a distinct bimodal fibrin fiber distribution. This difference in fibrin 
fiber distribution patterns may be a consequence of evolutionary differences between the three animal classes and their related processes of wound healing and thrombus formation. In light of the above discovery the utilization of reptilian species for the study of anti-thrombotic efficacy, in relation to humans, would be discouraged due to the their difference in fibrin fiber distribution which may have clinical implications in terms of the derived outcomes. The utilization of mammalian and avian models, at least in terms of fibrin fiber distribution patterns, would proved a suitable alternative for study - the utilization of the studied penguin, oryx and ovine species being greatly encouraged due to their statistical indifference in terms of their fibrin fiber size class size ranges in comparison to that of humans.

\section{ACKNOWLEDGEMENTS}

Acknowledgement to the following people and institutes who contributed to this project: Bayworld, PE, the National Zoological Gardens, Pretoria, University of Pretoria Biomedical Research Centre, and Onderstepoort Teaching Animal Unit for providing samples; Malcolm J. Smale (PhD), Bayworld Centre for Research and Education, Port Elizabeth Museum at Bayworld, Humewood; Antoinette Kotze (PhD), National Zoological Gardens, Pretoria; Ms Heleen Els, Onderstepoort Teaching Animal Unit, Faculty of Veterinary Science, University of Pretoria; staff at the University of Pretoria Biomedical Research Centre, Pretoria.

PRETORIUS, E.; VIEIRA, W. A.; OBERHOLZER, H. M. \& AUER, R. E. J. Microscopía electrónica de barrido comparativa de plaquetas y redes de fibrina de humano y de diferentes animales. Int. J. Morphol., 27(4):69-76, 2009.

RESUMEN: El propósito del presente estudio fue comparar la ultraestructura de plaquetas y las redes de fibrina de los seres humanos y de ocho diferentes especies de animales, con el fin de determinar las diferencias morfológicas de estas estructuras y si las diferencias pueden ser observadas por microscopía electrónica de barrido. Las plaquetas y las redes de fibrina desempeñan un papel importante tanto en el proceso de coagulación como, fisiológicamente en procesos alérgicos y mecanismos inmunológicos. Elgrosor de las redes de fibrina humana fue comparado con las del ratón (Mus musculus), equino (Equus caballus), mono vervet (Chlorocebus aethiops, anteriormente Cercopithecus aethiops, antílope Africano (Oryx gazella), ovino (Ovis aries), pingüino (Spheniscus demersus), conejo (Oryctolagus cuniculus) y tortuga marina (Caretta caretta). Las fibras fueron medidas y agrupadas en fibras delgadas (menor), fibras intermedias y fibras gruesas (grandes). Los resultados obtenidos indicaron que para cada una de las tres clases de fibrina, los rangos de su tamaño en el mono, antílope africano y en equino no fueron significativamente diferentes entre sí, mientras que en humano, pingüino, antílope africano y ovino no fueron significativamente diferentes entre éstos. De estos resultados se pudo concluir que mamíferos y aves poseen una distribución tri-modal de fibras de fibrina, distinta a la de las especies de reptiles estudiadas, donde la tortuga de mar posee una distribución bimodal de fibras de fibrina. Se puede sugerir que la utilización de los modelos mamíferos y aviar, en términos de patrones de distribución de fibras de fibrina, pueden ser una alternativa adecuada para los estudios ultraestructurales.

PALABRAS CLAVE: Microscopía electrónica de barrido; Plaquetas, Redes de fibrina; Humanos; Animales.

\section{REFERENCES}

Butenas, S. \& Mann, K. G. Blood coagulation. Biochemistry, 671:3-12, 2002.

Camera, M.; Giesen, P. L.; Fallon, J.; Aufiero, B. M.; Taubman, M.; Tremoli, E. \& Nemerson, Y. Cooperation between VEGF and TNF- is necessary for exposure of active tissue factor on the surface of human endothelial cells. Arterioscler. Thromb. Vasc. Biol., 19:531-7, 1999.

Cheryk, A.; Gentry, P. A.; Bast, T. \& Yamashiro, S. Alterations in the blood platelet morphology during aggregate formation in the Asian elephant Elephas maximus. J. Zoo. Wildl. Med. 29:177-82, 1998.

du Plessis, L.; Botha, A. J. \& Stevens, K. Ultrastructure of buffalo, Syncerus caffer, platelets: comparison with bovine and human platelets. J. Morphol., 229:309-14, 1996. du Plessis, L. \& Stevens, K. Blood Platelets of the African Elephant. J. Comp. Pathol., 127:208-10, 2002.

Ebbeling, L.; Robertson, C.; McNicol, A. \& Gerrard, J. M. Rapid ultrastructural changes in the dense tubular system following platelet activation. Blood, 80:718-23, 1992.

Herd, C. M. \& Page, C. P. Pulmonary immune cells in health and disease: platelets. Euro. Respir. J., 6:1145-60, 1994.

Lazarus, A. H.; Song, S. \& Crow, A. R. Understanding platelet function through signal transduction. Transfus. Med. Rev., 17:45-56, 2003.

Lui, L. P.; Shan, C. W.; Lui, X. H.; Xiao, H. C. \& Yang, S. Q. Effect of procainamide on ultrastructure of blood platelet in rabbits. Zhongguo. Yao. Li. Хие. Bao., 
PRETORIUS, E.; VIEIRA, W. A.; OBERHOLZER, H. M. \& AUER, R. E. J. Comparative scanning electron microscopy of platelets and fibrin networks of human and differents animals. Int. J. Morphol., 27(1):69-76, 2009.

194:376-9, 1998.

Pretorius, E.; Briedenhann, S.; Marx, J.; Smit, E.; van der Merwe, C. F.; Pieters, M. \& Franz, R. C. Ultrastructural comparison of the morphology of three different platelet and fibrin fiber preparations. Anat. Rec. (Hoboken), 290(2):188-98, 2007.

Zucker-Franklin, D.; Benson, K. A. \& Meyers, K. M. Absence of a surface-connected canalicular system in bovine platelets. Blood, 65:241-4, 1985.
Correspondence to:

E. Pretorius

Faculty of Health Sciences

BMW Building, PO Box 2034

University of Pretoria

Pretoria, SOUTH AFRICA

Tel number: +27 123192533

Fax: +27 123192240

Email: resia.pretorius@up.ac.za

Received: 15-09-2008

Accepted: 12-11-2008 